\title{
KOMUNITAS AMFIBI DI TWA KERANDANGAN PASCA MUSIM KEMARAU
}

\section{AMPHIBIAN COMMUNITY IN KERANDANGAN NATURAL PARK AFTER THE DRY SEASON}

\author{
Muhammad Syazali $^{1 *}$, Andri Sahria ${ }^{2}$, Ria Amelia $^{2}$, Lisa Alpina², Nadia Febriani², \\ ${ }^{1}$ Program Studi PGSD FKIP Universitas Mataram, Indonesia \\ ${ }^{2}$ IPM Universitas Pendidikan Mandalika Mataram, Indonesia \\ *Email: m.syazali@unram.ac.id
}

Diterima: 03 Juni 2020. Disetujui: 26 Agustus 2020. Dipublikasikan: 30 September 2020

\begin{abstract}
Abstrak: Amfibi merupakan herpetofauna yang berperan penting dalam aliran energi dan siklus biogeokimia di habitat perairan dan terestrial. Sebagai biota yang sangat tergantung pada habitat perairan, kemarau berpotensi untuk mempengaruhi komunitas amfibi. Fenomena tersebut dapat menjadi bencana lingkungan karena habitat perairan di TWA Kerandangan adalah sungai musim. Penelitian bertujuan untuk menganalisis komunitas amfibi di TWA Kerandangan. Analisis komunitas mencakup kelimpahan, indeks diversitas dan piramida umur. Pengumpulan data dilakukan pada malam hari diawal musim hujan dengan 5 kali ulangan. Metode yang digunakan adalah Nocturnal Cencus. Data dianalisis menggunakan kelimpahan relatif, indeks keanekaragaman Shannon-Wiener, indeks evennes, dan indeks dominansi. Piramida umur ditentukan berdasarkan jumlah amfibi muda (juvenile) dan dewasa. Hasil penelitian menunjukkan bahwa spesies yang paling melimpah adalah Limnonectes kadarsani $(\mathrm{Kr}=$ 63.64\%). Indeks keanekaragaman spesies rendah $\left(\mathrm{H}^{\prime}=0.86\right)$, namun komunitas amfibi di TWA Kerandangan stabil karena memiliki indeks kemerataan yang tinggi $(\mathrm{E}=0.78)$, dan indeks dominansi rendah $(D<0.05)$. Berdasarkan geometrinya, populasi Limnonectes kadarsani sedang mengalami pertumbuhan.
\end{abstract}

Kata Kunci: Diversitas, Kelimpahan Relatif, Musim Kemarau, Piramida Umur

\begin{abstract}
Amphibians are herpetofauna that important role for energy flow and biogeochemical cycle in aquatic and terrestrial habitat. As a biota that is highly dependent on aquatic habitat, dry season is a potentially to effect of amphibian community. The phenomenon can be an environmental disaster because aquatic habitat in Kerandangan Natural Park is a nonperenial river. Research obyective is to analyze of amphibian community in Kerandangan Natural Park. Community analyze including abundance, diversity index, and age pyramid. Data collection was conducted in night at the beginning of the rainy season (Desember 2019 - Januari 2020). The method used is Nocturnal Cencus. Data were analyzed using relative abundance, Shannon-Wiener index, evennes indeks and dominance index. The age pyramid is determined based on the number of juvenile and adult amphibians. The result show that the most abundant species is Limnonectes kadarsani (relative abundance $=63.64 \%$ ). Species diversity index is low $\left(\mathrm{H}^{\prime}=0.86\right)$, but amphibian community in Kerandangan Natural Park is stable because it have hight evennes index of species $(\mathrm{E}=0.78)$, and low dominance index $(D<0.05)$. Acording to it's geometry, the Limnonectes kadarsani population is experiencing growth.
\end{abstract}

\section{Keywords: Diversity, Relative abundance, Dry Season, Age Pyramid}

\section{PENDAHULUAN}

Amfibi merupakan herpetofauna yang berperan penting dalam aliran energi dan siklus biogeokimia di habitat perairan dan terestrial. Hampir semua amfibi, terutama ordo anura, memiliki fase tadpole yang hidup di air. Pada fase ini, amfibi memperoleh $\mathrm{O}_{2}$ dan nutrisi langsung dari habitat perairan. Sumber nutrisi tadpole berupa serasah dan berbagai jenis mikroplankton dan detritus [1 - 2]. Fungsinya sebagai herbivore menjadikan amfibi vektor penting terhadap pemindahan materi dan energi dari produsen ke alam dan predatornya. Sebagian energi dan materi tidak ditransfer, melainkan digunakan untuk proses pertumbuhan dan perkembangan dan memasuki fase juvenile [3].

Fase juvenile sampai dewasa bernafas menggunakan paru-paru dan hidup di habitat terestrial. Di habitat ini, amfibi adalah predator. Mangsanya mencakup berbagai jenis arthropoda dan cacing tanah [4 - 6]. Dibanyak jenis ekosistem terestrial, amfibi adalah prey dari berbagai jenis fauna bertulang belakang seperti ular dan burung karnivore [7]. Jika di perairan amfibi berperan dalam transfer materi dan energi dari produsen, maka di darat amfibi berperan dalam transfer materi dan energi dari konsumen. Ketika musim kawin, amfibi melakukan pemijahan di habitat perairan.

Proses pemijahan dan fase tadpole yang berlangsung di perairan menyebabkan kualitas air berpengaruh terhadap keberlangsungan hidup amfibi [8]. Kualitas air dapat dipandang dari aspek volume, fiisk dan kandungan kimiawi [9 - 10], serta periodesasi ketersediaannya di habitat [11]. Di Indonesia, periodesasi keberadaan air sungai 
tergantung pada musim. Salah satu sungai tersebut adalah sungai di TWA Kerandangan. Sungai ini merupakan sungai musim. Pada musim kemarau, volume airnya sangat sedikit sampai alirannya terputus karena terdapat banyak titik yang mengering. Fenomena tersebut dapat menjadi bencana lingkungan bagi komunitas amfibi.

Monitoring komunitas amfibi di TWA Kerandangan adalah kebutuhan karena amfibi berperan terhadap lingkungan dan sumber benefit bagi manusia [12]. TWA Kerandangan juga memiliki spesies amfibi endemik yaitu Limnonectes kadarsani [13]. Spesies ini hanya terdistribusi di Nusa Tenggara [14]. Berdasarkan IUCN Red List [15], trend populasi dari Limnonectes kadarsani adalah decreasing. Penelitian ini mengkaji kelimpahan, dan kenaekaragaman spesies di TWA Kerandangan pasca musim kemarau 2019. Secara khusus, studi ini juga mengkaji piramida umur Limnonectes kadarsani untuk mengetahui status populasinya.

Penelitian amfibi di TWA Kerandangan sebenarnya pernah dilakukan sejak tahun 2011. Namun masih terbatas pada keanekaragaman spesies [16] tanpa melihat faktor lingkungan seperti efek berkurangnya sumberdaya air akibat musim kemarau. Studi terkait struktur komunitas juga pernah dilakukan oleh [17], tapi sampelnya terbatas pada individu yang sudah dewasa. Hasil dari studi tersebut belum memberikan gambaran piramida umur yang merupakan informasi penting terkait status populasi dari Limnonectes kadarsani. Status populasi yang dimaksud adalah apakah populasi dari spesies endemik Nusa Tenggara tersebut sedang tumbuh, stasioner, atau penurunan. Penelitian ini dapat menjadi sumber informasi untuk manajemen konservasi amfibi di Kawasan TWA Kerandangan.

\section{METODE PENELITIAN}

\section{Waktu dan Tempat}

Penelitian dilaksanakan pada awal musim hujan (Desember 2019 - Januari 2020) di TWA Kerandangan. Lokasi sampling dibagi menjadi 3, yaitu area pondok kerja, sungai dan camping ground (Gambar 1). Untuk area sampling berupa sungai, area jelajah mencakup badan sungai dan kiri kanan sungai dengan lebar maksimal 15 meter mengacu [18]. Pencarian amfibi di area pondok kerja dan camping ground dilakukan dengan menjelajah seluruh area tersebut yang memungkinkan ditemukannya amfibi, seperti lantai tanah dan beton, serasah, celah batu, pohon, semak-semak pinggir tanah lapang, dan pot di sekitar pondok kerja.

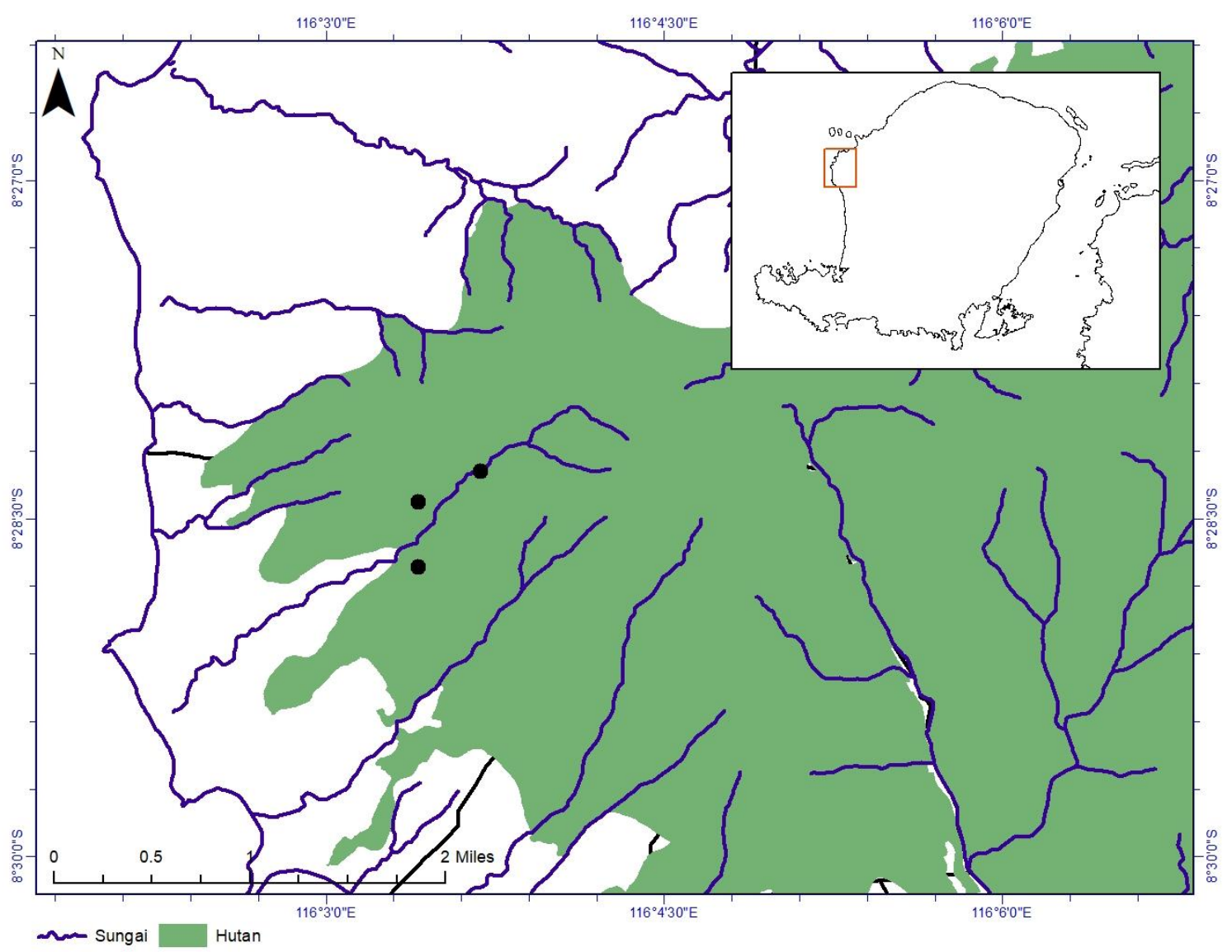

Gambar 1. Lokasi Sampling Amfibi di TWA Kerandangan. 


\section{Metode survey}

Survey dilakukan menggunakan metode Nocturnal Census seperti yang digunakan oleh [19]. Pengumpulan sampel dimulai dari pukul $20.00-$ 24.00. sampel dalam penelitian ini adalah amfibi dewasa yang ditentukan berdasarkan Snout to venth length (SVL) mengacu pada [14], [20]. Secara khusus, sampel untuk spesies Limnonectes kadarsani mencakup individu dewasa dan juvenile. Ukuran sampel ditentukan berdasarkan jumlah individu terbanyak dari masing-masing populasi selama $5 \mathrm{x}$ pengumpulan sampel. Periode pengambilan sampel adalah $1 \mathrm{kali} / \mathrm{minggu}$. Hal tersebut bertujuan agar pengambilan sampel dilakukan pada kondisi alami.

\section{Analisis data}

Analisis data terdiri dari kelimpahan relatif, indeks keanekaragaman dan piramida umur. Kelimpahan relatif ditentukan menggunakan persamaan:

$\mathrm{Kr}=\frac{n_{i}}{N} \times 100 \%$

Indeks keanekaragaman spesies dianalisis menggunakan indeks Shannon-Wiener:

$\mathrm{H}^{\prime}=-\sum p_{i} \ln p_{i}$

$$
\begin{aligned}
& \mathrm{E}=\frac{\mathrm{H}^{\prime}}{\ln \mathrm{S}} \\
& \mathrm{D}=\sum\left(\frac{n_{i}}{N}\right)^{2}
\end{aligned}
$$

Keterangan:

$\mathrm{Kr}=$ kelimpahan relatif $(\%)$

$\mathrm{n}_{\mathrm{i}}=$ jumlah individu spesies $\mathrm{i}$

$\mathrm{N}=$ jumlah individu seluruh spesies

$\mathrm{H}^{\prime}=$ indeks keanekaragaman spesies

$\mathrm{p}_{\mathrm{i}}=\mathrm{n}_{\mathrm{i}} / \mathrm{N}$

$\mathrm{E}=$ indeks kemerataan spesies

$\mathrm{S}=$ kekayaan spesies

$\mathrm{D}=$ indeks dominansi spesies

Piramida dibuat berdasarkan jumlah amfibi juvenile dan dewasa. Amfibi juvenile dan dewasa ditentukan berdasarkan Snout to Vent length (SVL) tiap spesies mengacu pada [14], [20], [21], [22]. Jumlah individu pada fase juvenile menjadi dasar/pondasi piramida, dan fase dewasa sebagai puncaknya.

\section{HASIL DAN PEMBAHASAN}

Spesies yang ditemukan selama pengamatan adalah 3 spesies yaitu Limnonectes kadarsani, Polypedates leucomystax, dan Duttaphrynus melanostictus. Jumlah individu dewasa dari masingmasing populasi kurang dari 10 individu (Tabel 1). Komposisi spesies ini lebih sedikit dibandingkan dengan penelitian sebelumnya [16], [17], [23].

\begin{tabular}{|c|c|c|c|c|c|}
\hline \multirow{2}{*}{ No } & \multirow{2}{*}{ Famili } & \multirow{2}{*}{ Spesies } & \multicolumn{2}{|c|}{ Jumlah (Individu) } & \multirow{2}{*}{$\begin{array}{c}\text { Kelimpahan relatif } \\
(\%)\end{array}$} \\
\hline & & & $\mathrm{J}$ & I & \\
\hline 1 & Dicroglossidae & Limnonectes kadarsani & 14 & 7 & 63.64 \\
\hline 2 & Rachoporidae & Polypedates leucomystax & 0 & 1 & 27.27 \\
\hline 3 & Bufonidae & Duttaphrynus melnostictus & 0 & 3 & 9.09 \\
\hline \multicolumn{3}{|c|}{ Total } & 14 & 11 & 100.00 \\
\hline
\end{tabular}

Tabel 1. Komposisi spesies amfiib di TWA Kerandangan

Dimana:

J = Juvenile; I = Imago

Kekayaan spesies yang rendah berimplikasi pada indeks keanekaragaman spesies. hasil analisis menunjukkan bahwa $H^{\prime}=0.86$. indeks diversitas yang lain memiliki nilai yang berkisar dari 0.49 sampai dengan 0.78 (Gambar 2).

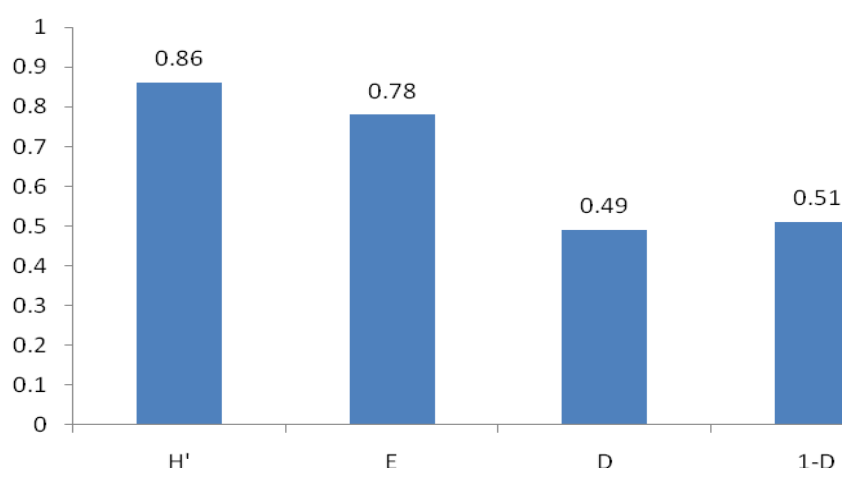

Gambar 2. Indeks diversitas amfibi 
Ditinjau dari geometri piramida umurnya (Gambar 3), populasi Limnonectes kadarsani sedang mengalami pertumbuhan. Jumlah individu pada fase juvenile lebih besar dibandingkan dengan jumlah individu fase dewasa. Struktur populasi ini dapat disebut sebagai strategi bertahan hidup pada kondisi lingkungan yang tidak menguntungkan. Jumlah invidu fase juvenile yang melimpah tersebut akan tumbuh dan berkembang menjadi individu-individu dewasa. Pada kondisi lingkungan yang menguntungkan di musim hujan, mereka akan bereproduksi untuk mempertahankan keberadaan jenisnya.

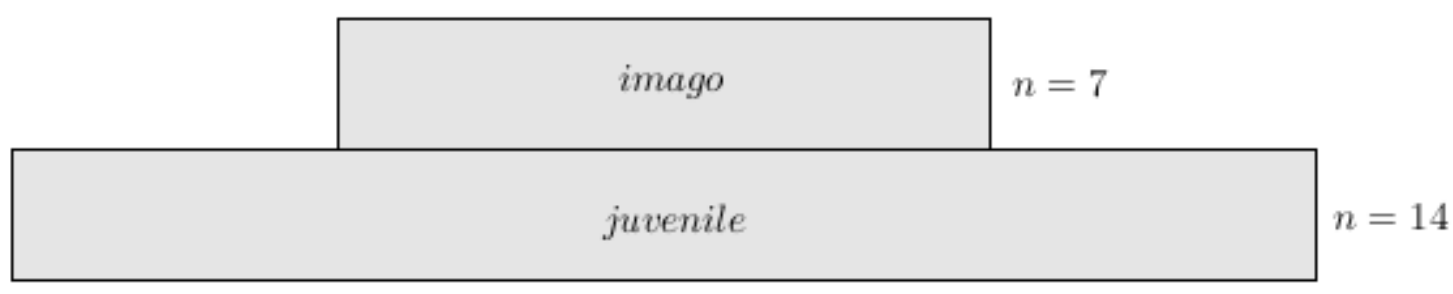

Gambar 3. Piramida umur populasi Limnonectes kadarsani di TWA Kerandangan

Spesies Limnonectes kadarsani adalah amfibi yang paling survive terhadap kondisi habitat oleh musim kemarau. Hal ini dikarenakan memiliki kelimpahan relatif paling tinggi (Tabel 1). Perubahan lingkungan oleh musim kemarau, baik sebagai seumberdaya dan kondisi, adalah density independent factor. Ketersediaan air yang bersifat periodik berdampak negatif terhadap amfibi [24 26]. Mengeringnya badan sungai dapat mengurangi kelembaban udara, dan peningkatan suhu di sekitarnya. Kondisi tersebut dapat mengurangi kesintasan amfibi karena mereka memerlukan kelembaban yang tinggi, dan suhu yang relatif rendah [27 - 28]. Lingkungan seperti ini diperlukan untuk mengurangi kehilangan kelembaban tubuh akibat evaporasi melalui kulit [29].

Faktor-faktor tersebut menyebabkan penurunan densitas dan kelimpahan amfibi [30]. Walaupun demikian, Limnonectes kadarsani adalah amfibi terbesar di Pulau Lombok. Spesies ini memiliki otot tungkai belakang yang berkembang dengan baik. Adaptasi morfologi tersebut dapat berfungsi dengan baik untuk berpindah dari badan sungai yang kering ke bagian yang masih memiliki genangan air. Warna punggungnya yang mirip serasah daun juga dapat dimanfaatkan untuk kamuflase, dan mengurangi resiko dimangsa oleh predator seperti ular dan hewan lainnya [31 - 32]. Predator ini sering ditemukan di sepanjang daerah aliran sungai (DAS) di TWA Kerandangan. Namun daya adaptasi tersebut tidak dapat menghindari adanya penurunan kelimpahan populasi.

Kelimpahan populasi penyusun komunitas adalah faktor yang mempengaruhi keanekaragaman amfibi [33 - 34]. Indeks keanekaragaman spesies yang rendah (Gambar 2) disebabkan oleh rendahnya kekayaan spesies [35]. Indeks keanekaragaman spesies juga berbanding lurus dengan indeks kemerataan [36], namun berbanding terbalik terhadap indeks dominansi [37]. Kekayaan spesies sendiri tergantung pada sumberdaya dan kondisi lingkungan [38 - 40]. Karakteristik lingkungan menjadi faktor pembatas bagi spesies amfibi [41], sehingga hanya spesies-spesies adaptif yang dapat survive. Di Pulau Lombok, spesies yang paling adaptif adalah Duttaphrynus melanostictus karena dapat ditemukan di berbagai tipe habitat, termasuk di TWA Kerandangan [42].

Di TWA Kerandangan, populasi yang sedang mengalami pertumbuhan adalah Limnonectes kadarsani (Gambar 2). Jumlah juvenile lebih besar dibandingkan dengan jumlah dewasa. Kondisi ini dapat dikatagorikan sebagai strategi bertahan menghadapi kondisi yang tidak menguntungkan pada musim kemarau. Strategi tersebut menjadi salah satu faktor yang menyebabkan Limnonectes kadarsani salah satu spesies yang memiliki densitas terbesar di Pulau Lombok [43]. Walaupun spesies ini masih kalah adaptif dibandingkan dengan Duttaphrynus melanostictus karena hanya mampu sintas di hutan [42]. Ditinjau dari aspek lain, hal tersebut justru menguntungkan karena dapat dimanfaatkan sebagai bioindikator. Selain itu Limnonectes kadarsani hanya dapat ditemukan di sungai yang tidak tercemar di hutan primer dan sekunder [14].

Selain sebagai bioindikator, Limnonectes kadarsani juga dapat dimanfaatkan sebagai sumber protein. Berdasarkan penuturan polisi hutan yang bertugas di TWA Kerandangan, sering ditemukan oknum masyarakat yang menangkap jenis katak ini menggunakan listrik. Masalah tersebut dapat mengancam keberadaan Limnonectes kadarsani di kawasan karena penangkapan untuk konsumsi menjadi satu faktor pemicu berkurangnya populasi amfibi secara global. Walaupun mayoritas masyarakatnya adalah muslim, namun Indonesia merupakan salah negara pengekspor paha katak terbesar di dunia [44]. Kasus ini harus menjadi perhatian seluruh pihak, teutama BKSDA NTB. Informasi terkait diversitas amfibi karena faktor alam seperti musim kemarau juga dapat menjadi acuan dalam melakukan upaya konservasi. Konsep ecocentric etics yang mengkombinasikan aspek ekologi, ekonomi, budaya dan teknologi perlu 
dijadikan faktor intervensi untuk konservasi di TWA

\section{KESIMPULAN}

Spesies yang predominan adalah

Limnonectes kadarsani. Indeks keanekaragaman spesies amfibi tergolong rendah, namun indeks kemerataannya tinggi sehingga tidak ada spesies yang dominan pada komunitas amfibi di TWA Kerandangan. Populasi Limnonectes kadarsani sedang mengalami pertumbuhan.

\section{DAFTAR PUSTAKA}

[1] Jacobson, B., Cedeno-Vazquez, J. R., Espinoza-Avalos, J., \& Gonzalez-Solis, D. (2019). The effect of diet on growth and metamorphosis of Triprion petasatus (anura: hylidae) tadpoles. Herpetological Conservation and Biology, 14(2), 308-324.

[2] Kloh, J. S., Figueredo, C. C., \& Eterovick, P. C. (2018). You are what, where, and when you eat: seasonal and ontogenetic changes in a tropical tadpole's diet. Amphibia-Reptilia, 39, 445-456.

[3] Craioveanu, O., Craioveanu, C., Ghira, I., Mireșan, V., \& Hartel, T. (2019). Does carnivory pay off? Experiments on the effects of different types of diet on growth and development of Bufo bufo (Linnaeus, 1758) tadpoles and carry-over effects after metamorphosis. Herpetozoa, 31, 21-31.

[4] Bahuguna, V., Chowdhary, A. K., Singh, S., Bhatt, G., Bhardwaj, S., Lohani, N., et al. (2019). A food spectrum analysis of three bufonid species (Anura: Bufonidae) from Uttarakhand region of the western Himalaya, India. Journal of Threatened Taxa, 11(13): 14663-14671.

[5] Marques-Pinto, T., Barreto-Lima, A. F., \& Brandão, R. A. (2019). Dietary resource use by an assemblage of terrestrial frogs from The Brazilian Cerrado. North-Western Journal of Zoology, 15(2): 135-146.

[6] Solé, M., Dias, I. R., Rodrigues1, E. A., Marciano-Jr, E., Branco, S. M., \& Rödder, D. (2019). Diet of Leptodactylus Spixi (Anura: Leptodactylidae) from a cacao plantation in Southern Bahia, Brazil. North-Western Journal of Zoology, 15(1): 62-66.

[7] Fadel, R. M., Thaler, R., Folly, H., Galvão, C., Hoffmann, M., Alves, L., Santana, D. J., \& Mângia, S. (2019). Predation of anurans across multiple life stages in an Amazon - Cerrado transitional zone. Herpetology Notes, 12, 895899.

[8] Woolrich-Pina, G. A., Smith, G. R., BenitezTadeo, R. A., Lemos-Espinal, J. A., \& Morales-Garza, M. (2017). Effects of salinity and density on tadpoles of Incilius occidentalis from Oaxaca, Mexico. Copeia, 105(1): 43-45.
Kerandangan.

[9] Shaikh, K., Memon, S., Gachal, G., \& Yusuf, S. (2017). A comprehensive assessment of habitats for amphibian fauna in Taluka Larkana , district. Journal of Entomology and Zoology Studies, 5(6), 1737-1742.

[10] Tagar, I., Shaikh, K., Gachal, G. S., \& Arain, I. (2019). Assessment of anurans (frogs and toads) inhabiting district Naushahro Feroze, Sindh, Pakistan. Journal of Entomology and Zoology Studies, 7(1), 1419-1422.

[11] Mendes, L., Dorado-rodrigues, T. F., Chupel, T. F., \& Penha, J. (2016). Vegetation structure and hydroperiod affect anuran composition in a large neotropical wetland vegetation structure and hydroperiod affect anuran composition in a large neotropical wetland. Herpetologica, 72(3), 181-188.

[12] West, J. (2018). Importance of Amphibians : A Synthesis of Their Environmental Functions, Benefits to Humans, and Need for Conservation. Bridgewater State University.

[13] Monk, K. A., De Fretes, Y., \& ReksodiharjoLilley, G. (2000). Ekologi Nusa Tenggara dan Maluku. Jakarta: Prenhallindo.

[14] Iskandar, D. T., Boeadi, \& Sancoyo, M. (1996). Limnonectes kadarsani (Amphibia: Anura: Ranidae), a new frog from the Nusa Tenggara Islands. Raffles Bulletin of Zoology, 44(1), 21-28.

[15] Iskandar, D. T., \& Mumpuni. (2004). Limnonectes kadarsani. The IUCN Red List of Threatened Species.

[16] Kadir, A. (2011). Keanekaragaman Amfibi (Ordo Anura) di TWA Kerandangan. Universitas Mataram.

[17] Handayani, M. Fi. (2011). Struktur Populasi Katak Jabrak (Limnonectes kadarsani) di TWA Kerandangan. Universitas Mataram.

[18] Kusrini, M.D. 2009. Pedoman Penelitian dan Survey Amfibi di Alam. Bogor: Fakultas Kehutanan IPB.

[19] Gillespie, G. R., Howard, S., Stroud, J. T., U1hassanah, A., Campling, M., Lardner, B., Scroggie, M. P., \& Kusrini, M. (2015). Responses of tropical forest herpetofauna to moderate anthropogenic disturbance and effects of natural habitat variation in Sulawesi, Indonesia. Biological Conservation, 192, 161173.

[20] Kusrini, M. D. (2013). Panduan Bergambar Identifikasi Amphibia Jawa Barat. Bogor: Institut Pertanian Bogor.

[21] Iskandar, D. T. (1998). The Amphibians of Java and Bali. Jakarta: Research and Development Centre for Biology-LIPI.

[22] Zug, G. R., \& Kaiser, H. (2014). A new species 
of four-toed skink (Squamata: Scincidae: Carlia peronii species group) from Pulau Suku, Indonesia, and biogeographic notes on the herpetofauna of Flores and Komodo. Proceedings of the Biological Society of Washington, 126(4), 379-392.

[23] Syazali, M. (2017). Keanekaragaman Amfibi Lombok dan Pengembangannya sebagai Bahan Ajar Ekologi di SMA. Universitas Mataram.

[24] Greenberg, C. H., Zarnoch, S. J., \& Austin, J. D. (2017). Weather, hydroregime, and breeding effort influence juvenile recruitment of anurans: Implications for climate change. Ecosphere, 8(5).

[25] Mendes, L., Dorado-rodrigues, T. F., Chupel, T. F., \& Penha, J. (2016). Vegetation structure and hydroperiod affect anuran composition in a large neotropical wetland vegetation structure and hydroperiod affect anuran composition in a large neotropical wetland. Herpetologica, 72(3), 181-188.

[26] Valerio, L. M., Da, R. T. F., Chupel, T. F., Penha, J., \& Strussman, C. (2016). Vegetation structure and hydroperiod affect anuran composition in a large neotropical wetland. Herpetologica, 72(3), 181-188.

[27] Brattstrom, B. H. (1963). A preliminary review of the thermal requirements of amphibian. Ecology, 44, 238-255.

[28] Syazali, M., Idrus, A. Al, \& Hadiprayitno, G. (2017a). Analisis Multivariat dari Faktor Lingkungan yang Berpengaruh terhadap Struktur Komunitas Amfibi di Pulau Lombok. Jurnal Pendidikan Biologi, 10(2), 68-75.

[29] Toledo, R. C., \& Jared, C. (1993). Review: Cutaneous adaptations to water balance in amphibians. Camp. Biochum. Ph,Ssiol., 10(4), 593-608.

[30] Huang, C., \& Hou, P. L. (2004). Density and diversity of litter amphibians in a Monsoon Forest of Southern Taiwan. Zoological Studies, 43(4), 795-802.

[31] José, D., Capela, V., Struett, M. M., \& Leivas, P. T. (2020). Predation attempt of Rhinella ornata (Spix , 1824) (Anura, Bufonidae ) by Leptodactylus cf. latrans (Anura, Leptodactylidae) in the Atlantic Forest, Brazil. Herpetology Notes, 13, 11-13.

[32] Roberto, I. J., \& Souza, A. R. (2020). Review of prey items recorded for snakes of the genus Chironius (Squamata, Colubridae), including the first record of Osteocephalus as prey. Herpetology Notes, 13, 1-5.

[33] Riyanto, A. (2011). Herpetofaunal community structure and habitat associations in Gunung Ciremai National Park, West Java, Indonesia. Biodiversitas, 12(1), 38-44.

[34] Shahriza, S., Ibrahim, J., \& Anuar, S. M. S. (2013). Amphibian of Tupah Recreational
Forest, Merbok, Kedah, Malaysia. Malays. Appl. Biol., 42(2), 71-75.

[35] Muslim, T., \& Sari, U. K. (2016). Keanekaragaman herpetofauna di lahan reklamasi tambang batubara PT Singlurus Pratama, Kalimantan Timur. Seminar Nasional Biologi 2016, 1-8.

[36] Siahaan, K., Dewi, B. S., \& Darmawan, A. (2019). Keanekaragaman amfibi ordo anura di Blok Perlindungan dan Blok Pemanfaatan Hutan Pendidikan Konservasi Terpadu, Taman Hutan Raya. Jurnal Sylva Lestari, 7(3), 370378.

[37] Indrawati, Y., Hanifa, B. F., Septiadi, L., \& Alwi, M. Z. (2018). Keanekaragaman jenis herpetofauna nokturnal di area Coban Jahe, Desa Pandansari Lor, Kecamatan Tumpang, Kabupaten Malang, Jawa Timur. Prosiding Seminar Nasional VI Hayati 2018, 277-286.

[38] Cayuela, H., Cruickshank, S. S., Brandt, H., Ozgul, A., \& Schmidt, B. R. (2019). Habitatdriven life history variation in an amphibian metapopulation. Oikos, 1-12.

[39] Eakin, C. J., Calhoun, A. J. K., \& Hunter, M. L. (2019). EffEcts of suburbanizing landscapEs on reproductive effort of vernaL pool-breeding amphibians. Herpetological Conservation and Biology, 14(2), 515-532.

[40] Holtmann, L., Philipp, K., Becke, C., \& Fartmann, T. (2017). Effects of habitat and landscape quality on amphibian assemblages of urban Effects of habitat and landscape quality on amphibian assemblages of urban stormwater ponds. Urban Ecosyst, 1-11.

[41] Bruni, G., Ricciardi, G., \& Vannini, A. (2016). Effectiveness of artificial amphibian breeding sites against non-native species in a public protected area in Tuscany, Italy. Conservation Evidence, 13, 12-16.

[42] Syazali, M., Idrus, A. Al, \& Hadiprayitno, G. (2019). Habitat characteristic and conservation of amphibians in Lombok Island. Biota: Jurnal Biologi Dan Pendidikan Biologi, 12(2), 98107.

[43] Syazali, M., Idrus, A. Al, \& Hadiprayitno, G. (2017b). Densitas amfibi di Pulau Lombok, Nusa Tenggara Barat. Biologi Tropis, 17(2), 53-58.

[44] Kusrini, M. D., \& Alford, R. A. (2006). Indonesia's exports of frogs' legs. TRAFFIC Bulletin, 21(1), 13-24. 